\title{
POTENTIAL IMPACT OF A PROPOSED RAILWAY TUNNEL ON THE KARST ENVIRONMENT: THE EXAMPLE OF ROSANDRA VALLEY, CLASSICAL KARST REGION, ITALY-SLOVENIA
}

\author{
POTENCIALNI VPLIV NAČRTOVANEGA ŽELEZNIŠKEGA \\ TUNELA NA KRAŠKO OKOLJE: PRIMER DOLINE GLIŠICE, KRAS, \\ ITALIJA-SLOVENIJA
}

\author{
Luca ZINI ${ }^{1}$, Luca VISINTIN ${ }^{1}$, Franco CUCCHI ${ }^{1} \&$ Walter BOSCHIN ${ }^{1}$
}

\begin{abstract}
UDC 551.44:621.332.8(450+497.4)

Luca Zini, Luca Visintin, Franco Cucchi \& Walter Boschin: Potential impact of a proposed railway tunnel on the karst environment: the example of Rosandra valley, Classical Karst Region, Italy-Slovenia

Val Rosandra is a unique geomorphological environment located on the western side of the Classical Karst Plateau (NE Italy). This deep limestone gorge is crossed by a stream that is fed by a large basin located in Slovenia. Val Rosandra is the only example of a karst river valley with surface hydrography in the Classical Karst Plateau. The torrent that crosses it digs a deep gully into the rock, rich in rapids, swirl holes, small waterfalls, enclosed meanders and basins; here, the first seepage phenomena occur, and part of the water feeds the underground aquifer.Val Rosandra is characterised by a complex structural situation. The NE slope culminates in the structure of Mt. Stena, a limestone tectonic wedge between two faults, firmly rooted in the karst platform. Both its external morphology and its caves are influenced by the structure, i.e. by the attitude of bedding planes, fault planes and master joints. Mt. Stena, in particular, hosts a comprehensive net of articulated and diversely shaped caves, basically organised on several levels. This network stretches over a total of 9,000 metres, bearing testimony to ancient geological and hydrogeological origins. The deepest areas of the system reach a suspended aquifer that is probably sustained by an overthrust and placed about 100 meters above the underground aquifer of the Rosandra torrent. A series of feasibility studies on the Trieste-Divača high-speed railway link concentrated on the potential interaction between the project and karst features. In line with the project requirements, risk of voids intersection and water contamination were analyzed as Mt. Stena's suspended aquifer partially feeds the Rosandra torrent, which flows in a protected natural area. We therefore suggest that further investigations ought to be performed to integrate the existing knowledge on karst and on the hydrogeological aspects of the massif.
\end{abstract}

Keywords: tunnel construction, karst hazards, karst aquifer, Classical Karst.
Izvleček

UDK 551.44:621.332.8(450+497.4)

Luca Zini, Luca Visintin, Franco Cucchi \& Walter Boschin: Potencialni vpliv načrtovanega železniškega tunela na kraško okolje: Primer doline Glišice, Kras, Italija-Slovenija

Dolina Glinšice je geomorfološko pomembno območje na zahodnem delu Krasa (SV Italija). Gre za globoko vrezano strugo potoka $\mathrm{z}$ zaledjem $\mathrm{v}$ Sloveniji, ki je edini primer kraškega vodotoka s površinsko hidrografijo na klasičnem krasu. Za tok Glinšice so značilne številne brzice, majhni slapovi, meandri in erozijske kotlice. Del toka se izgublja v podzemlje. Strukturna slika območja je precej kompleksna. SV pobočje preide v hrib Stena, ki predstavlja apnenčasti klin med dvema prelomoma, trdno usidran v planoto Krasa. Površinska morfologija in jame v Steni so močno strukturno pogojene V Steni je razvejana mreža kraških jam razvitih v več nivojih. Skupna dolžina znanih jam je $9 \mathrm{~km}$. Najgloblji deli jamskega sistema dosežejo dno vodonosnika, ki je zaradi narivanja kakih $100 \mathrm{~m}$ nad vodonosnikom povezanim s potokom Glinšica. Niz študij izvedljivosti hitre železnice Divača-Trst, obravnava vpliv načrtovanega projekta na kraške pojave. $V$ njih so preučene možnosti sekanja večjih jamskih prostorov in onesnaženja vode, saj vodonosnik v Steni deloma napaja potok Glinšico, ki je del zavarovanega območja. $\mathrm{V}$ članku predlagamo nadaljnje raziskave $\mathrm{v}$ smislu povezovanja obstoječega znanja o krasu in konkretnih hidrogeoloških razmer v obravnavanem masivu.

Ključne besede: gradnja tunelov, tveganja na krasu, kraški vodonosnik, klasični kras.

\footnotetext{
${ }^{1}$ Department of Geosciences, University of Trieste (Italy), e-mails: zini@units.it; luca.visintin@phd.units.it; cucchi@units.it; walter.boschin@units.it
}

Received/Prejeto: 9.9.2010 


\section{INTRODUCTION}

Corridor 5 - the high-speed railway line that is due to connect Lisbon and Kiev through Italy running for over 4000 kilometres - crosses extremely varied soils and rocks and encounters virtually all conceivable geological problems. Based on the current status of the project, crossing of the Classical Karst area is planned with the construction of a tunnel running approximately 50 kilometres between Monfalcone (Italy) and Divača - This stretch, which develops almost in its entirety in karstified limestone, should host the connections to the stations of Trieste (Italy) and Koper (Slovenia) and to their ports (Fig. 1).
The project entails the excavation of two paired tunnels with a diameter of approximately $15 \mathrm{~m}$ and a distance between centres of 25/30 m (excavation area approximately $700 \mathrm{~m}^{2}$ ).

Specific problems arise in the sector of Val Rosandra where the railway line is expected to cross the border between Italy and Slovenia underground of a regional park. Val Rosandra is a unique geomorphological environment located in the south-eastern limb of the Classical Karst plateau. This deep limestone gully develops between two areas (Karst and Čičarija) with completely different structures (Fig. 1).

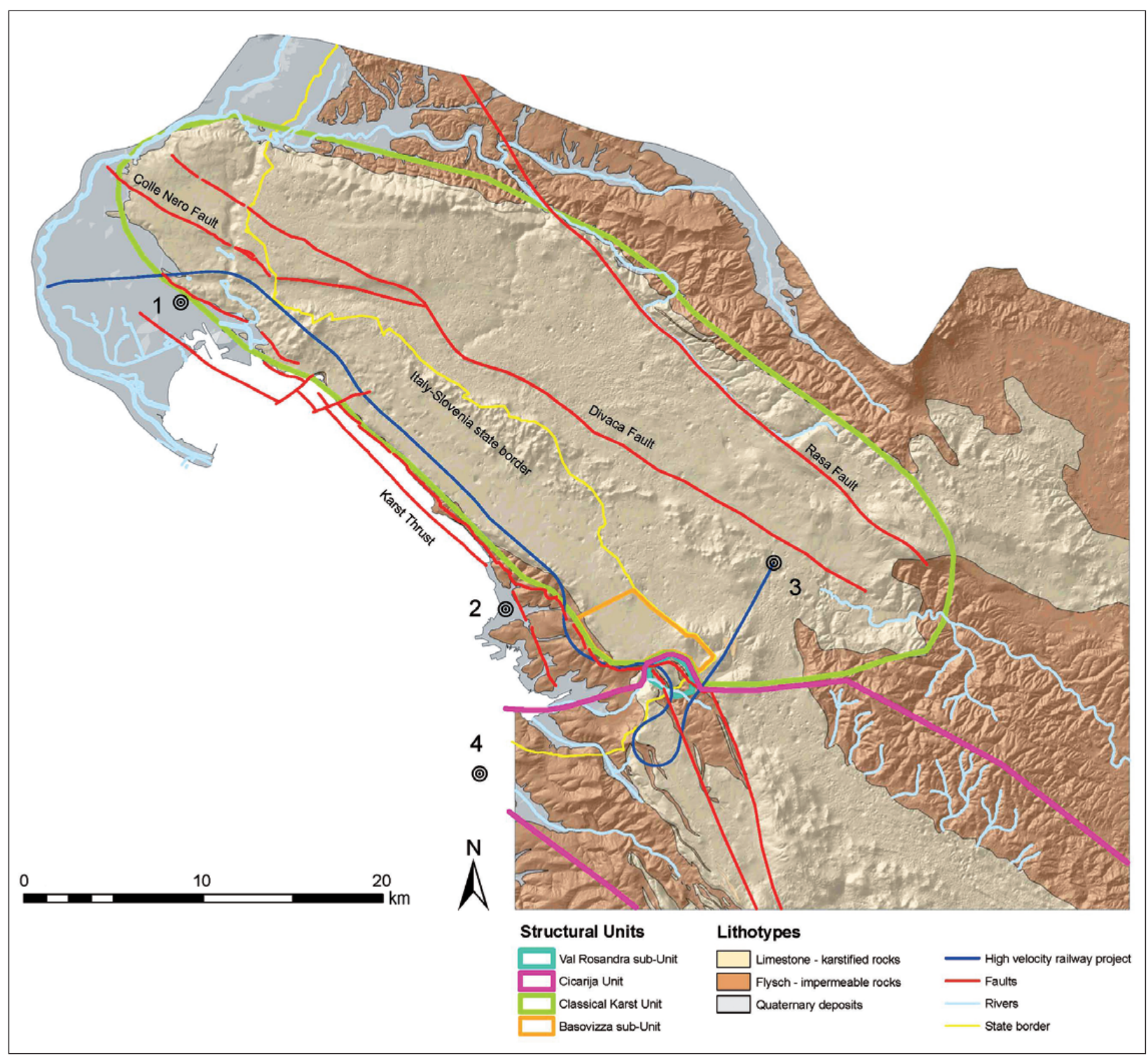

Fig. 1: Simplified structural map of the area interested by the railway project extended to the whole Classical Karst. 1-Monfalcone (I), 2-Trieste (I), 3-Divaca (Slo), 4-Koper (Slo). 
There, it interacts not only with the caves that are already known to the researchers, but also with groundwater. The above-mentioned park is the Regional Natural Reserve of Val Rosandra, established in 1996 in line with Council Directive 92/43/EEC, also known as the Habitat Directive (Cucchi et al. 2005).
This paper aims at illustrating and discussing the geological, geomorphological and hydrogeological studies conducted to evaluate the potential impact of the railway line on the karstic environment and on the hydrodynamics of Val Rosandra.

\section{GEOLOGICAL OVERVIEW}

The "Classical Karst" is a wide morpho-karstic unit that extends to the South-East of River Isonzo up to Postojna. It contains all possible epigean and hypogean karst forms, whose concentration, dimensions and typology have turned this area into the worldwide symbol of karst phenomena.

As far as its general geological evolution is concerned, the Classical Karst belongs to the "Karst-Friuli carbonate platform", a northern offshoot of the "Adria plate". In lithological terms, the platform is formed by a thick sequence of rocks that are prevailingly carbonate in nature. This sequence dates back to the Triassic period at the bottom and to the Eocene period at the top of the succession and is overlaid by the flysch, a clast-quartzfeldspar-limestone succession (Cucchi et al. 1987a).

Underground karst phenomena are highly developed (Furlani et al. 2009): Mt. Stena, in particular, hosts a wide network of articulated and diversely shaped caves, basically organised onto four levels, for a total length of 9,000 metres. Three caves (Fessura del Vento cave, Martina cave, Gallerie cave) intercept an aquifer suspended on marls rooted among the limestone scales that form Mt. Stena.

The construction of tunnels in karst regions confronts many problems due to the unpredictable location, shape and dimension of karst voids (Day 2004; Shang et al. 2004; Xeidakis et al. 2004; Casagrande et al. 2005; Knez et al. 2008; Peila \& Pelizza 2009; Ismail et al. 2010). The study also tried to evaluate the potential impact of railway tunnel works on the hypogean environment, and especially on seepage and groundwater, in order to avoid any impact on the karst ecosystem.

A multidisciplinary approach was therefore adopted to review existing knowledge on the subject and specifically to supplement this knowledge with targeted geological, technical, speleological, geomorphological and hydrogeological surveys.

The Val Rosandra is characterised by outcrops of limestone belonging to the Trieste Karst Limestone Group, as well as sandstone and marls belonging to Trieste's Flysch, which are unevenly covered by quaternary deposits (Cucchi et al. 1987b). Limestone, which features medium - high karstifiability, forms the aquifer, whereas flysch, which is substantially non-karstifiable, forms the aquiclude.

The basis of the succession is composed of Alveolina and Nummulitic Limestone (Palaeocene - Lower Eocene). This limestone mainly comprises compact bioclastic grainstone with a thickness of approximately $200 \mathrm{~m}$, as well as abundant macro-foraminifera. The stratification is decimetric to metric. The upper part of the succession is characterised by alternations of limestone and marls that anticipate the arrival of flysch siliciclastic turbidites. These are "transitional beds" (Eocene) formed by marly limestone with millimetric to centimetric stratification and by so-called "fucoid marls", lamellar lutites that can reach a thickness of up to 15 metres. These lithotypes are not karstified and have a key impact on underground water circulation as they are impermeable (Fig. 2). The succession ends with Trieste's flysch (Eocene), which consists of an alternation of marls and sandstone levels with variable thickness. Marls are millimetre- to centimetre-scale thick, whereas sandstone's thickness varies from a centimetric to a metric scale (Tirelli et al. 2008).

These formations are unevenly covered by recent deposits which consist of scree fan and breccias, derived from alluvial and eluvial-colluvial deposits sometimes cemented.

From a structural point of view (Fig. 1), the Classical Karst Plateau is a wide geological unit known as the "platform of Komen", which is characterised by a slightly asymmetrical anticline trending NW-SE and whose structure is complicated by a set of secondary folds and faults (Placer 1981). Val Rosandra (Val Rosandra subunit) is the westernmost part of the imbricate Čičarija structure (Čičarija unit), which enters into contact with the southern offshoot of the Classical Karst unit (Basovizza sub-unit) through an overthrust (the Carso thrust) with E-W trend (Cucchi et al. 2002a).

The area of Val Rosandra is characterised by a set of small thrusts with NE dip direction, which culminate in Mt. Stena structure and overlay a series of concentric 

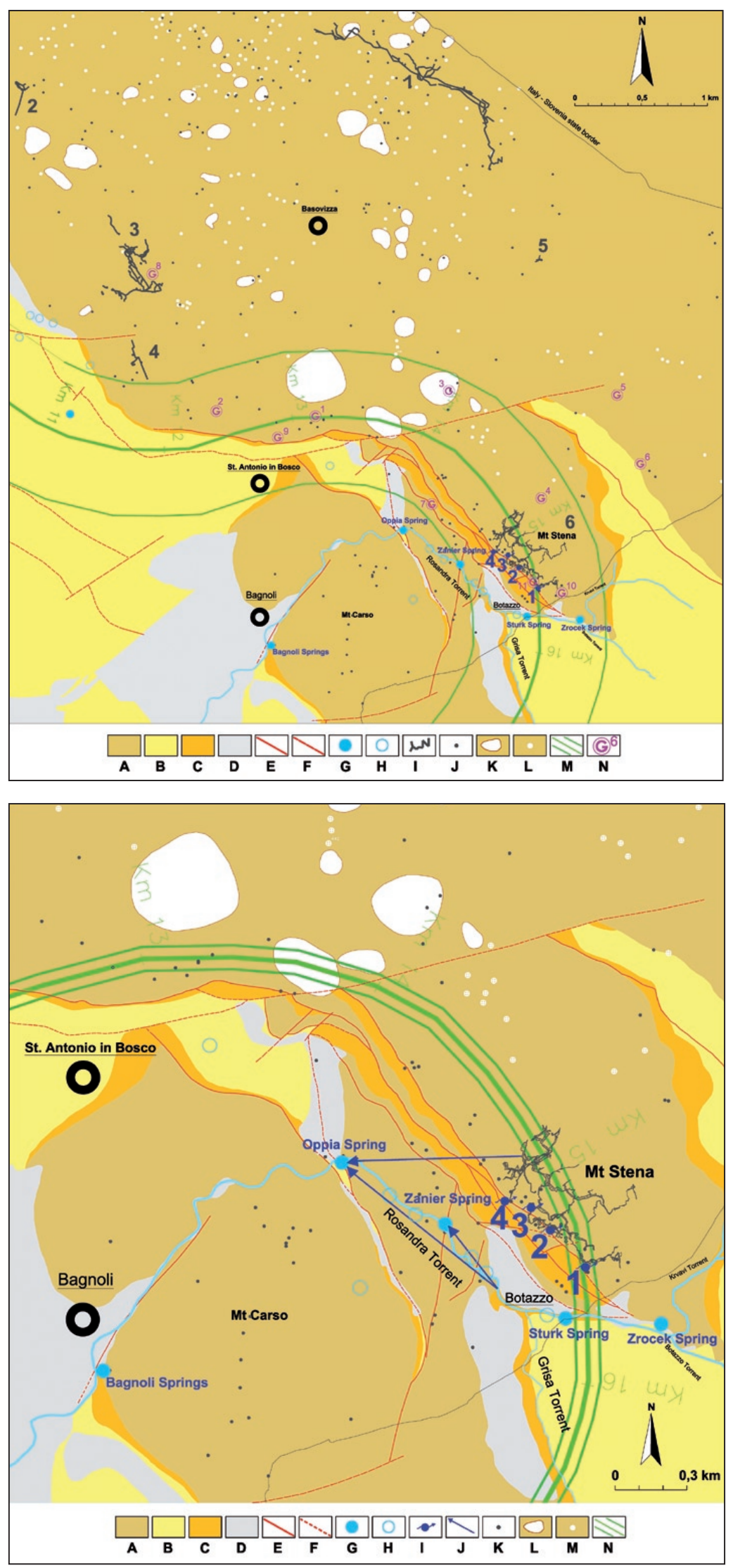

Fig. 2: Geological map of the studied area. 1-Claudio Skilan Cave, 2-Padriciano Cave, 3-Impossible Cave, 4-Cava Italcementi Cave, 5-Diavolo Abyss, 6-Mt Stena Cave System, A-Limestone, B-Flysch, C-Marls,

D-Quaternary deposits, E-Geological Structure, F-Supposed Geological Structure G-Perennial spring, $H$-Temporaneous spring, I-Main cave passage, J-Minor cave entrance, $K$-Main doline (more than $100 \mathrm{~m}$ diameter), L-Minor doline (less than $100 \mathrm{~m}$ diameter), $M$-Railway project trace (whidest line) and the $500 \mathrm{~m}$ buffer contour (thinnest lines), $N$-Geomechanical site (the number is linked to Tab. 1).

folds, the most significant of which is the anticline of Mt. Carso. The fronts of these thrusts are moderately dislocated by small tear faults (Fig. 3).

The rock mass has been characterised through 11 geomechanical monitoring sites (nine external and two in the caves) in different geological and structural contexts. In order to identify the main joint sets, the data has been analyzed by means of Schmidt stereographical projection using Dips 4.0 software. BRMR classification has been applied to define the quality of rock masses (Bieniawski 1989); it ranges between class II good and IV - poor with prevalence of class III - fair.

Fig. 3: Detailed geological map of the Mt. Stena area. 1-Martina Cucchi Cave, 2-Gallerie Cave, 3-Gualtiero Savi Cave, 4-Fessura del Vento Cave, A-Limestone, B-Flysch, C-Marls, D-Quaternari deposits, E-Geological Structure, F-Supposed Geological Structure, G-Perennial spring, H-Temporaneous spring, I-Cave with water with ancient flow direction, J-Determined underground water flow connection, K-Cave entrance, $L$-Main doline (more than $100 \mathrm{~m}$ diameter), M-Minor doline (less than $100 \mathrm{~m}$ diameter), $\mathrm{N}$-Railway project trace (whidest line) and the $500 \mathrm{~m}$ buffer contour (thinnest lines). 


\section{GEOMORPHOLOGICAL OVERVIEW}

Val Rosandra is the only example of a karst river valley with surface hydrography in the Italian part of the Classical Karst. It is crossed by a torrent fed by an approximately $40 \mathrm{~km}^{2}$ - large basin. This basin develops almost entirely in the siliciclastic deposits of Trieste's flysch and grants the Rosandra torrent water-flow rates that can also be quite high during rainy periods (Cucchi et al. 2005).

Underground karst phenomena are highly developed: Mt. Stena, in particular, hosts a wide network of articulated and diversely shaped caves, basically organised onto four levels, for a total length of 9000 metres. Three caves (Fessura del Vento cave, Martina cave, Gallerie cave) intercept an aquifer suspended on marls rooted among the limestone wedges that form Mt. Stena (Cucchi \& Zini 2009).

Understanding the extent and type of hypogean karstification implies comprehending the extent and type of karstification that characterise the Classical Karst Plateau. To this aim, we have conducted a statistical analysis of karst features to be found in the Italian sector of the Classical Karst, i.e., an area of approximately $140 \mathrm{~km}^{2}$ (Cucchi et al. 2001; Cucchi \& Zini 2002b). The area of Basovizza and Val Rosandra sub-units, also affected by the project, has been thoroughly analysed by means of geomorphological surveys, both on the surface and in the caves (Fig. 3).

On the surface, particular attention was given to dolines, sinkholes, karst landforms and to the forms that could suggest recent tectonic activities. Inside the caves, the surveys concentrated on evaluating the structural impact on the evolution of caves, on the type of filling deposits and on reconstructing the parts of caves that had been filled.

The railway line crosses the underground portion of the south-eastern limb of the Basovizza sub-unit and Mt. Stena, which is the northern part of the Val Rosandra sub-unit. The mountain gently dips towards the north, whereas its southern slope rapidly and steeply plunges towards the Rosandra torrent.

An over 30-m high waterfall marks the passage between flysch and limestone. This is followed by a deep gully excavated in rocks, rich in rapids, pot-holes, small waterfalls, enclosed meanders and basins.

The river bed is subject to constant diversions as it follows the main discontinuity sets present in the rock mass for some kilometres. There it engraves its ancient alluviums, until it reaches the sea. The slopes that overlook the Rosandra torrent are characterised by scarps and rocky cliffs, overhanging rocks, peaks, scree fans and large mobilised blocks, which are the expression of a faceted lithology and complex tectonics. The numerous faults that characterise the area give high energy to the slope, thus causing selective erosion to make formations even harsher.

On the surface, the most relevant landforms in terms of deep karstification are dolines. Their morphometry has been analysed (maximum, minimum and medium diameter, depth, plan shape, shape of slopes, filling material and shape of bottom) in order to detect their genesis (solution doline or collapse doline, unroofed cave) and their depth (Andriani et al. 2001; Knez \& Slabe 2005; Mihevc et al. 1998; Mihevc 1999; Slabe 1997; Šušteršič 1994).

The Carso thrust which separates the two structural units (Basovizza sub-unit and Val Rosandra sub-unit) also marks the border between two geomorphological units, which differ in terms of surface karst phenomena (Cucchi et al. 2001).

Two distinct areas have, in fact, been identified: dolines are rather abundant in one of them, whereas they cannot be found in the other. In the area that features the most evolved karst phenomena - the Basovizza subunit - many collapse and dissolution dolines have been identified, twenty of which with diameter exceeding 100 $\mathrm{m}$. On top and at the foot of Mt. Stena, the Val Rosandra sub-unit, only a roofless cave and ten small dolines can be found (Fig. 2).

With a view to assessing the type and extent of the underground karst phenomena, we have surveyed all the caves in Trieste's Karst for which reliable data are available (2,516 out of the 3,089 caves known in 2009).

On the basis of the speleological surveys conducted, we have calculated the ratio between plan development (S) and depth (P) of all caves. When this ratio is lower than 0.7 , caves feature a prevailing vertical development, whereas when the value exceeds 1.3 , voids are mainly horizontal. S/P values between 0.7 and 1.3 refer to the coalescence of vertical shafts (Piccini 2005).

These surveys permitted to identify three main types of caves, each with different distribution and concentration characteristics and, consequently, with relevant geotechnical problems:

- passages with prevalent sub-horizontal or slightly inclined development (type HC),

- shafts with prevalent vertical development (type $\mathrm{VC}$ ),

- complex caves where horizontal passages, shafts and chambers form a diffuse network (type CC).

In geometrical terms, the volumes involved in types $\mathrm{HC}$ and VC can be represented as cylinders, whereas those of the CC type as polyhedrons. 
In the Val Rosandra sub-unit, two are the most frequent - and therefore most easy to intercept - morphologies: galleries developed in contact between limestone and transitional beds and galleries that evolved into canyons (type $\mathrm{HC}$ ). In the Basovizza sub-unit, the most frequent form is the shaft, with diameter of 1-10 m and total depth of some dozens of metres (type VC). Less frequent are complex shafts (type CC). Rare $(<1 \%)$ are the ancient routes of the ancient Timavo system (type $\mathrm{HC}$ ), with massive galleries (diameter up to 50-60 m and depth also over $100 \mathrm{~m}$ ) extending over several kilometres (Casagrande et al. 2005; Visintin 2007). The latter are probably the most critical forms from a geotechnical point of view: they are, in fact, large voids that can occasionally collapse, thus forming dolines.

The two sub-units under examination include 291 caves listed in the cave registrar of the area (221 in the Basovizza sub-unit and 70 in the Val Rosandra subunit).

To better understand the influence of the structural features of the rock mass on the development of caves, the attitude of 100 discontinuity planes has been assessed in 33 monitoring sites (23 in the Val Rosandra sub-unit and 10 in the Basovizza sub-unit). The statistical distribution of the poles that characterise the 199

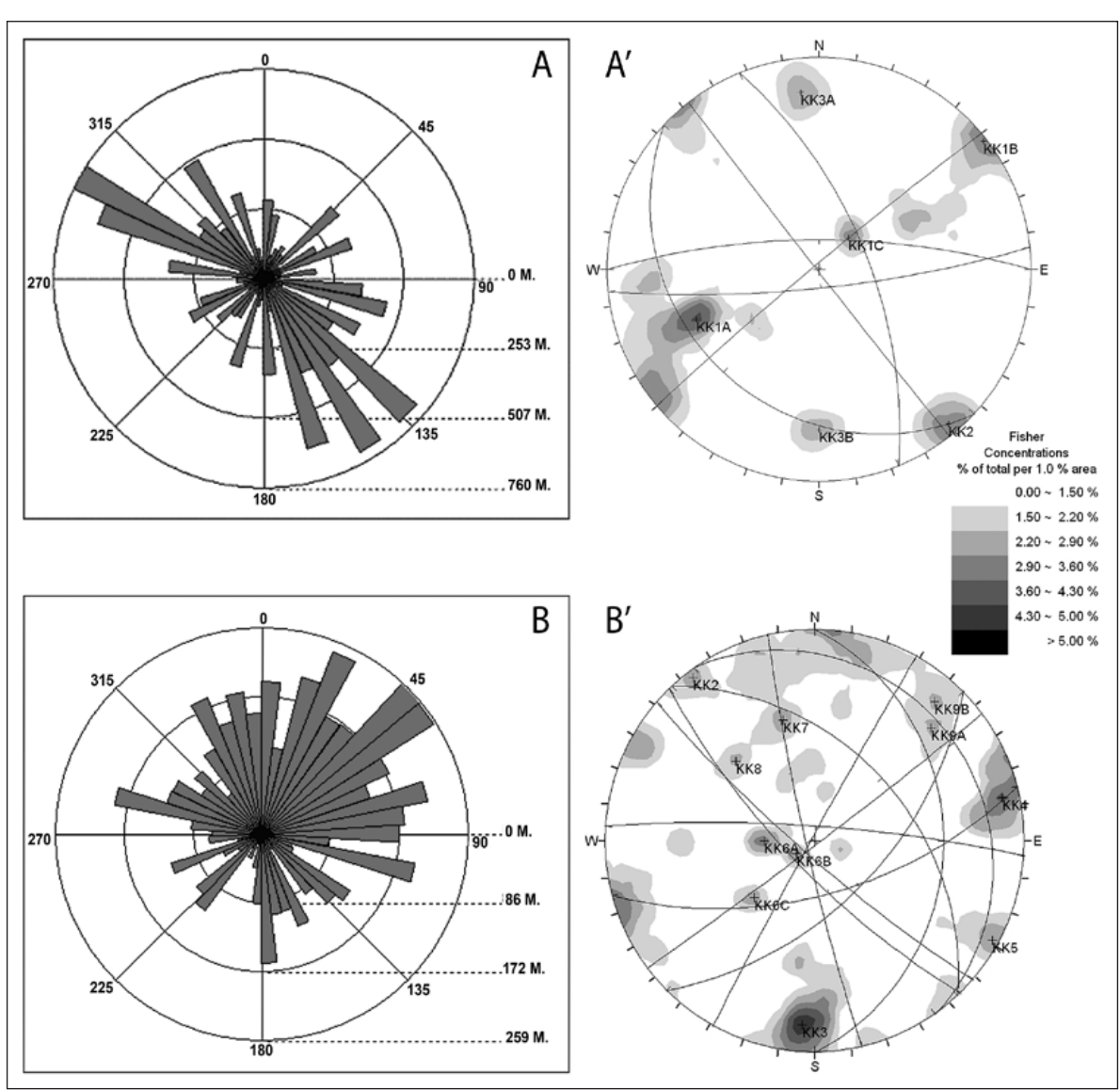

discontinuity sets identified is shown on the graphs of Fig. 4. The over $23 \mathrm{~km}$ of caves present in the study area (about 9,000 $\mathrm{m}$ of which are located in the Val Rosandra sub-unit and $14,000 \mathrm{~m}$ in the Basovizza sub-unit) have been summarised through vectors that show the different cave stretches in order to compare the geometry of the caves (Cucchi 1989) with that of the discontinuity surfaces (Fig. 4).

The theoretical/synthetic representations show that the development trends coincide with those of some of the main discontinuity sets that characterise the carbonate massif (Fig. 4).

Confronting the different development and discontinuity directions that characterise the caves permits to identify the most relevant discontinuity sets in terms of karstification and hydrogeology. This enables researchers to assume the probable further development of caves even when this has not yet been directly surveyed or cannot be surveyed by speleologists.

In the Rosandra sub-unit, at least 5 discontinuity sets influence the shape and orientation of caves: KK2, KK3, KK4, KK5, KK9 (Fig. 4). Among them, KK2 (NESW sub vertical) and KK3 (E-W dipping towards N) influence most of the caves. The situation changes in the Basovizza sub-unit, where the structural situation in relatively simpler and caves are influenced by systems KK1A, KK1B and secondarily by KK2 (Fig. 4).

In order to assess direct interferences between caves and the rail line, all of the caves located within a $500 \mathrm{~m}$ wide buffer have been examined.

Fig. 4: Rose diagrams showing the directions of the caves ( $A=$ Basovizza sub-unit; $B=V a l$ Rosandra sub-unit) and polar diagrams (Schmidt stereographycal projection, lower hemisphere) of joints ( $A^{\prime}=$ Basovizza sub-unit; $B^{\prime}=$ Val Rosandra sub-unit). 
Inside the buffer, 66 caves have been identified: the largest ten (San Lorenzo cave, Voragine di San Lorenzo cave, Ferroviaria cave, Pipistrelli cave, Altari cave, Pepi di Botazzo cave and Mt. Stena cave system) have been selected as the most representative based on morphometric, morphological and genetic data and have been thoroughly surveyed from a geological and geomorphological viewpoint. Four of these caves belong to the so-called Mt Stena cave system (Cucchi et al. 1998): the Gualtiero Savi cave (4,000 m development), the Fessura del Vento cave (2,600 m development), the Martina Cucchi cave (over 2,000 m development) and the Gallerie cave (almost 1,000 m development). These caves develop on different levels between 370 and $220 \mathrm{~m}$ asl. They consist in sub-horizontal passages, often canyons, whose continuity is sometimes interrupted by large collapse chambers. The filling deposits are significant and diversified: besides usual speleothems and clayey deposits, also polygenetic conglomerates have been observed, sometimes cemented on walls and ceilings.

The five largest caves in the Basovizza sub-unit have also been analysed (Claudio Skilan cave, Padriciano cave,
Impossibile cave, Italcementi cave, Diavolo abyss). Even though these caves are situated outside of the $500 \mathrm{~m}$ wide buffer area, surveying them has been deemed useful to understand the karst genesis of the whole area.

In the zone under examination, the spatial distribution of the different types of caves, their morphology, etc., confirm the substantial difference in karst genesis between the area to the north (Basovizza sub-unit) and the area to the south (Val Rosandra sub-unit) of the Carso thrust (Fig. 1).

The northern area is characterised by prevailingly vertical caves, some of which, such as the Voragine di San Lorenzo, could be connected to large underground chambers, almost collapse dolines.

The hypogean complex inside Mt. Stena is rather large but its voids do not reach the sizes of the nearby caves of the Basovizza sub-unit (such as the Impossibile cave and the Skilan cave).

Val Rosandra area's speleogenetic engines are the Rosandra torrent and the paleo-Rosandra, whereas the northern area falls within the speleogenetic model of the Classical Karst and of the Reka-Timavo river.

\section{HYDROGEOLOGICAL OVERVIEW}

Torrent Rosandra originates from the confluence of two water streams, Botazzo and Griza. The Botazzo stream is fed by the Zroček spring, to the right of the river bank at $200 \mathrm{~m}$ asl (average discharge of some tens of $1 / \mathrm{s}$ ) and by the Šturk spring, at $183 \mathrm{~m}$ asl (average discharge a few $1 / \mathrm{s}$ ), both located in Slovenia, quite close to the Italian border (Fig. 3).

Near the village of Botazzo, the torrent - which up to this point has a basically stable discharge due to the impermeable nature of flysch - forms a 30-m waterfall which marks the passage from marly-sandstone rocks to the underlying limestone.

Many other springs contribute to feeding the torrent (Fig. 5): the Zaniér spring (124 $\mathrm{m}$ asl, maximum discharge approximately $10 \mathrm{l} / \mathrm{s}$ ), which flows from the Antro delle Ninfe cave, the Oppia spring (96 $\mathrm{m}$ asl, variable discharge ranging from a few $1 / \mathrm{s}$ to some hundreds $1 / \mathrm{s}$ ) and the group of springs of Bagnoli (Abbeveratoio spring, Lavatoio spring, Antro di Bagnoli resurgence), located between 62 and $65 \mathrm{~m}$ asl and with water discharges of

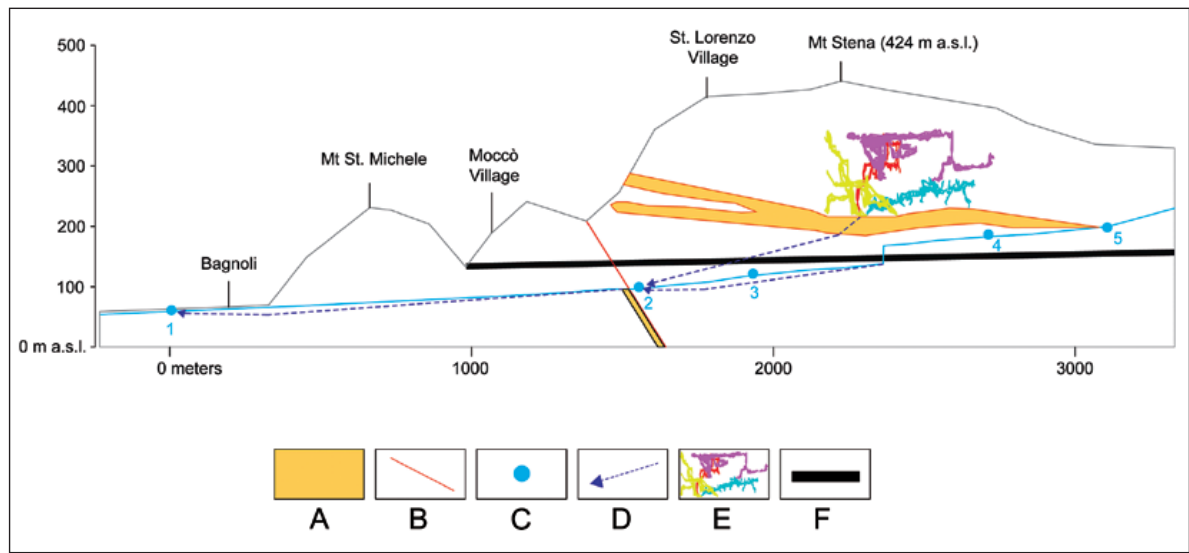

Fig. 5: Scheme along the Rosandra Torrent. 1-Bagnoli Springs, 2-Oppia Spring, 3-Zanier Spring, 4-Sturk Spring, 5-Zrocek Spring, A-Impermeable marls, B-Crinale Fault, C-Spring location, D-Underground determined drainage, E-Mt Stena Cave System (Fessura del Vento Cave - yellow, Gualtiero Savi Cave - pink, Gallerie Cave red, Martina Cucchi Cave - pale blue), F-Railway tunnel project location. 
over $1 \mathrm{~m}^{3} / \mathrm{s}$ in high-water periods and of approximately $18 \mathrm{l} / \mathrm{s}$ in low-water periods (Sancin 1988).

The surface discharge of Rosandra when the torrent reaches the plain ranges between $3-4 \mathrm{~m}^{3} / \mathrm{s}$ in high-water periods and a few $1 / \mathrm{s}$ in low-water.

The first seepage phenomena occur near the lake below the waterfall (138 $\mathrm{m}$ asl). As the discharge is lower than $4 \mathrm{l} / \mathrm{s}$, the water is completely absorbed and the riverbed downstream is entirely dry till it reaches the Oppia spring, where water partially reappears. In the stretch between the Oppia spring and Bagnoli, other seepages occur which, in turn, feed the Abbeveratoio spring (Sancin 2008).

The hypogean aquifer inside Mt. Stena is strongly influenced by the lithological structure. The transitional beds edges involved in the overthrusts (Figs. 3 and 5) sustain some aquifers located mostly between $226 \mathrm{~m}$ asl (Martina cave and Gallerie cave) and $215 \mathrm{~m}$ asl (Fessura del Vento cave). In the latter, water is sustained by marls and already flows at an altitude of $235 \mathrm{~m}$ asl with discharges between 0.7 and $8.5 \mathrm{l} / \mathrm{s}$. Quite likely, this water is also fed by that flowing occasionally in the Savi cave at an altitude of approximately $277 \mathrm{~m}$ asl.
Within the hydrostructure of Mt. Stena, two water-circulation domains can be identified: one feeds the Zroček spring upstream of Botazzo on the eastern slope, whereas the other the Zaniér and Oppia springs on the southern slope.

A tracer test has confirmed a connection between the Fessura del Vento and Fonte Oppia (Figs. 3 and 5), whereas no data is available on the route followed by the water present in the Martina and Gallerie caves (Brun \& Semeraro 2005). The latter may be supposed to feed the springs located on the southern slope but, given its altitude (226 m asl), even its contribution to the eastern ones cannot be excluded.

The relations between these "suspended" aquifers and the base level are not clear yet. As according to Civita (2005) the Oppia spring has a subordinate permeability threshold, it can be assumed that the base flow connected with the Rosandra torrent must be situated at an altitude between $96 \mathrm{~m}$ asl (Oppia spring), $120 \mathrm{~m}$ asl (Zanier spring) and $138 \mathrm{~m}$ asl (the foot of the waterfall). In medium or high-flow periods, in the 1-km stretch between the waterfall and the Oppia spring, groundwater recharges the torrent, whereas during low-flow periods the torrent recharge groundwater (Fig. 5).

\section{INTERACTION BETWEEN THE PROJECT AND KARST FEATURES}

In order to mark the interactions between underground karst forms and the two paired tunnels in the project, the study concentrated on the dolines and the caves that intersect the 50-meter buffer zone (Fig. 3). A total of two dolines and 18 caves intersect the buffer area (Tab. 1). Even though none of the explored stretches intersects the tunnels directly, 3 caves have a plan development that exceeds $1000 \mathrm{~m}$ and further 3 go deeper than $50 \mathrm{~m}$. Therefore, hints have been searched at a possible underground development of cave stretches that are now filled with deposits and cannot therefore be explored.

The further development of these caves cannot be directly ascertained due to the presence of deposits that hinder the passage. Therefore, the main primary (phreatic and epiphreatic as looping tubes, canyons, shafts,) and secondary (vadose galleries filled with various deposits, collapse chambers,) morphologies have been mapped based on the results of specific surveys conducted in the caves, in order to assume any possible development that could intersect the tunnels.

The thickness of the filling deposits has been evaluated through direct observation of the shafts present in the deposits themselves and by comparing these stretches with the ones that were only partially filled. In the Val Rosandra sub-unit, deposits with a thickness of up to 40 $\mathrm{m}$ have been found. This fact suggests that the caves may develop deeper and may therefore intersect the tunnels. The Basovizza sub-unit hosts some of the largest caves in the Classical Karst, which feature deep canyons and large chambers (such as in the Grotta Impossibile 130 x 65 x 75 $\mathrm{m}$ ) that are partially or totally obstructed by massive collapses. Nonetheless, the geomorphological characteristics of the 5 caves included in the buffer permit to exclude the presence of large chambers at the altitude of the tunnel.

Only a few of the total caves present in the area are known. Therefore, geomorphological statistical analyses have been applied to assess the type of unknown caves that could be encountered during the excavation works. As in the Val Rosandra sub-unit, two are the most frequent morphologies - galleries developed in contact between limestone and transitional beds and galleries that evolved into canyons (type HC) - basing on the caves that can be explored it can be argued that the average width of voids is between 6 and $8 \mathrm{~m}$ and their depth between 10 and $30 \mathrm{~m}$. In the majority of cases, the caves are partially or completely filled by filling deposits and/ 
Tab. 1: Caves with entrance located inside the $50 \mathrm{~m}$ wide buffer around the planned railway tunnel. HC - passages with prevalent subhorizontal or slightly inclined development; VC - shafts with prevalent vertical development; CC - complex caves where horizontal passages, shafts and chambers form a diffuse network.

\begin{tabular}{|c|c|c|}
\hline \multicolumn{3}{|c|}{ Basovizza sub-unit } \\
\hline $\begin{array}{l}\text { Cad. } \\
\text { num. }\end{array}$ & CAVE NAME & $\begin{array}{l}\text { CAVE } \\
\text { TYPE }\end{array}$ \\
\hline 492 & CAVERNETTA DELLA TRINCEA & $\mathrm{HC}$ \\
\hline 821 & POZZO PRESSO S. ANTONIO IN BOSCO & VC \\
\hline 1685 & CAVERNETTA AD E DELLA QUOTA 395 & $\mathrm{HC}$ \\
\hline 5768 & GROTTA $1^{\circ}$ SUL COSTONE & CC \\
\hline 6426 & POZZETTO DELLA STALATTITE MACROFAGO & VG \\
\hline & & \\
\hline & & \\
\hline & & \\
\hline & & \\
\hline & & \\
\hline & & \\
\hline & & \\
\hline
\end{tabular}

\begin{tabular}{l|l|c}
\hline \multicolumn{2}{|c}{ Val Rosandra sub-unit } \\
\hline $\begin{array}{l}\text { Cad. } \\
\text { num. }\end{array}$ & CAVE NAME & $\begin{array}{c}\text { CAVE } \\
\text { TYPE }\end{array}$ \\
\hline 290 & GALLERIE CAVE & $\mathrm{HC}$ \\
\hline 292 & CAVERNA IN VAL ROSANDRA & $\mathrm{HC}$ \\
\hline 527 & GROTTA DEI PIPISTRELLI & $\mathrm{HC}$ \\
\hline 928 & POZZETTO SOPRA LA GROTTA DEL TASSO & $\mathrm{VC}$ \\
\hline 930 & FESSURA DEL VENTO CAVE & $\mathrm{HC}$ \\
\hline 945 & CUNICOLO DI VAL ROSANDRA & $\mathrm{HC}$ \\
\hline 1435 & FERROVIARIA CAVE & $\mathrm{HC}$ \\
\hline 1696 & GROTTA PRESSO LA 3027 VG & $\mathrm{HC}$ \\
\hline 3557 & ANTRI SOPRA LA GROTTA DELLE GALLERIE & $\mathrm{HC}$ \\
\hline 4274 & GROTTA DELLA GALLERIA SOPRA BOTTAZZO & $\mathrm{CC}$ \\
\hline 4910 & MARTINA CUCCHI CAVE & $\mathrm{HC}$ \\
\hline 5080 & GUALTIERO SAVI CAVE & $\mathrm{HC}$ \\
\hline 5218 & CUNICOLO A N DI BOTTAZZO & $\mathrm{HC}$ \\
\hline
\end{tabular}

or collapse deposits and now only the higher portions of the galleries are accessible.

In the Basovizza sub-unit, an intersection of unknown shafts (type VC) with a diameter of 1-10 m and a depth of some dozens of metres is more probable. The intersection of large voids or massive galleries (diameter up to $50-60 \mathrm{~m}$ and depth also over $100 \mathrm{~m}$ - type CC) is very unlikely but it is the most important geotechnical problem.

As the number of significant outcrops in the area is rather limited, analysing cave developments has proven a useful tool to define tectonic and morphological domains that would otherwise be difficult to identify. This process has permitted to identify the discontinuity sets that are most affected by karstic phenomena and the areas of the project where the probability to encounter large voids is higher. Hydrogeological surveys have been conducted to investigate the potential impact of the project on the karst network that drains water within Mt. Stena hydrostructure.

The evaluation of the hydrogeological characteristics of the area involved, as well as of the details of the

project development, has led to assume a potential interception of part of the water-draining network hosted by the hydrostructure under consideration (Cucchi \& Zini 2002a). Firstly, even though hypogean water routes and draining conditions are not entirely clear, an interception of the waters of Mt. Stena cave complex is probable, especially if one considers that the project runs approximately $70 \mathrm{~m}$ below the deepest cave voids. Within this context, water circulation is probably linked to a prevailingly vadose system. Nonetheless, the presence of suspended aquifers have been proven. A section of the railway tunnel runs very close to Šturk spring - $33 \mathrm{~m}$ below - and the Zroček spring - $50 \mathrm{~m}$ below - and under the Bottazzo stream. An interaction with the saturated zone that feeds the spring in question appears therefore highly probable and could imply violent water spills at the excavation face. This could lead to a decrease in the discharge of the springs that feed the torrent due to the interception of water flows in Mt. Stena hydrostructure. It may also corrupt the quality of spring water due to contamination of the aquifer that feeds them.

\section{CONCLUSION}

From a strictly geological point of view, the project poses a few problems.

In the Basovizza sub-unit, a hundred-metre section of the railway tunnels will surely intercept the karst forms located below the large dolines near S. Lorenzo. Some faults are also expected to be crossed, with consequent geotechnical and hydraulic problems. Anticipated problems, for which solution ought to be planned 
but which could be resolved by improving the quality of the rock mass (injections, impermeabilisation, anchoring), include flows of red soils along karstified sub-vertical beds, increases in water levels during rainfalls, major voids.

As the Carso thrust is a water divide, hypogean water in this sector pertains to the whole Classical Karst area and any interception will not therefore impact Val Rosandra sub-unit hydrodynamics.

The cross-analysis of geological and structural data and of the caves surveys has permitted to identify the caves which will potentially interact with the railway tunnel. In the Basovizza sub-unit, very deep vertical shafts with small diameter prevail, whereas in the Val Rosandra sub-unit galleries and canyons prevail. In both cases the real void distribution is hidden by infilling deposits and by collapsed material. Voids which will be intercepted during the tunnels excavation will not be large but the major problems will occur due to the low geotechnical and geomechanical characteristics of the infilling material.

In the Val Rosandra sub-unit, from a hydrogeological viewpoint, the potential interaction of the project with the karst network that drains water inside Mt. Stena structure has been investigated. In this framework, particular attention was given to the consequences that the execution of the project could have for the quality of Val Rosandra waters and the discharge of the Rosandra torrent and of the springs present in the area.

Greater problems may arise from the critical issues of hydrogeological nature that characterise Mt. Stena underground. Given the distribution of caves and the proposed route of the railway line, the interception of part of the draining network present in the epikarst of the hydrostructure involved is certain. Šturk and Zroček springs are located within close distance and at a higher altitude than the railway tunnels: an interaction with the suspended saturated zone that feeds the spring is therefore sure.

Even though groundwater flow lines are thoroughly known, an interception of the waters present in the cave complex is highly probable because the tunnels are planned at an altitude of $140-150 \mathrm{~m}$ asl, just $70 \mathrm{~m}$ below the explored deepest cave voids. Although at these altitudes water circulation basically consists in vadose zone percolation, the presence of suspended aquifers may determine violent water incursions. The water drained by the railway tunnels would furthermore be channelled towards lower altitudes, i.e., towards the Karst area and, hence, taken away from the Val Rosandra aquifer.

A certain outcome will be a decrease of the discharge of the springs that feed the Rosandra torrent due to the interception and deviation of water flows in Mt. Stena hydrostructure.

Given the low discharge rate of the Rosandra torrent, it is highly probable that the construction of the tunnel will also determine a worsening in the quality of underground water (Civita 2005) due to contamination in the excavation phase (gasoline, oils, explosives, etc.).

In conclusion, given the hydrogeological context in which the project develops, the impact of underground works will definitely be notable, both in the construction and in the operating phase. One can legitimately foresee considerable consequences on the discharge rate and quality of water (Ii \& Kagami 1997; Vincenti et al. 2009), and hence on the related ecosystem.

\section{AKNOWLEDGEMENTS}

We wish to thank ITALFERR S.p.A. who have provided the financial support to our researches.

\section{REFERENCES}

Andriani, F., Cucchi, F., Marinetti, E. \& L. Zini, 2001: Doline di crollo e doline di dissoluzione nel Carso triestino.- Studi Trentini di Scienze Naturali, Acta Geologica, 77, 119-126.
Bieniawski, Z.T., 1989: Engineering Rock Mass Classification.- Publ. Wiley, pp. 251, New York. 
Brun, C. \& R. Semeraro, 2005: Test di tracciamento alla Fessura del Vento (Val Rosandra, Carso): nuove ipotesi sull'idrogeologia carsica dell'area. - [Online] Available from: http://www.gssg.it [Accessed $12^{\text {th }}$ January 2010].

Casagrande, G., Cucchi, F. \& L. Zini, 2005: Hazard connected to railway tunnel construction in karstic area: applied geomorphological and hydrogeological surveys.- Natural Hazards and Earth System Sciences, 5, 2, 243-250.

Civita, M., 2005: Idrogeologia applicata e ambientale.CEA Editor, pp. 736, Milano.

Cucchi, F., Pirini Radrizzani, C. \& N. Pugliese, 1987a: The carbonate stratigraphic sequence of the Karst of Trieste (Italy).- Memorie Società Geologica Italiana, 40, 35-44.

Cucchi, F., Finocchiaro, F. \& F. Vaia, 1987b: The geology of T. Rosandra valley (Karst of Trieste, Italy).Memorie Società Geologica Italiana, 40, 67-72.

Cucchi, F., 1989: Analisi delle caratteristiche morfostrutturali delle cavità dell'area di S. Ninfa.- Memorie dell'Istituto Italiano di Speleologia, 3, II, 93-100.

Cucchi, F., Potleca M. \& L. Zini, 1998: Origin and development of cave system in the Rosandra Valley (Classical Karst - Italy).- Acta carsologica, 27, 2, 63-74.

Cucchi, F., Marinetti, E., Potleca, M. \& L. Zini, 2001: Influence of geostructural conditions on the speleogenesis of the Trieste Karst (Italy).- Geologica Belgica, 4, 3-4, 241-250.

Cucchi, F. \& L. Zini, 2002a: Underground Timavo River monitoring (Classical Karst).- Acta Carsologica, 31, $1,75-84$.

Cucchi, F. \& L. Zini, 2002b: Considerations on the speleogenesis in the Trieste Classical Karst.- Memorie Società Geologica Italiana, 57, 481-486.

Cucchi, F., Mereu, A., Oberti, S., Piano, C., Rossi, A. \& L. Zini, 2005: Geology and geomorphology of the "Rosandra" valley for a cultural enhancement.- Il Quaternario, 18, 1, 185-196.

Cucchi, F. \& L. Zini (Eds.) 2009: Paesaggi carsici nel Friuli Venezia Giulia.- DiSGAM_Università di Trieste \& R.A. Friuli Venezia Giulia, pp. 112, Trieste.

Day, M. J., 2004: Karstic problems in the construction of Milwaukee's Deep Tunnels.- Environmental Geology, 45, 6, 859-863.

Furlani, S., Cucchi, F., Forti, F. \& A. Rossi, 2009: Comparison between coastal and inland Karst limestone lowering rates in the northeastern Adriatic Region (Italy and Croatia).- Geomorphology, 104, 73-81.
Knez, M. \& T. Slabe, 2005: Unroofed caves are an important feature of karst surfaces: examples from the classical karst.- Zeitschrift für Geomorphologie, 46, 2, 181-191.

Knez, M., Slabe T., Sebela S. \& F. Gabrovsek, 2008: The largest karst cave discovered in a tunnel during motorway construction in Slovenia's Classical Karst (Kras).- Environmental Geology, 54, 711-718.

Ii, H. \& H. Kagami, 1997: Groundwater level and chemistry changes resulting from tunnel construction near Matsumoto City, Japan.- Environmental Geology, 31, 76-84.

Ismail, S., Mansor, S., Rodsi, A. \& B. K. Bujang, 2010: Geotechnical modeling of fractures and cavities that are associated with geotechnical engineering problems in Kuala Lumpur limestone, Malaysia.[Online] Available from: Environmental Earth Sciences, http://beta.springerlink.com/earth-and-environmental-science/ [Accessed $8^{\text {th }}$ April 2010].

Mihevc, A., Slabe, T. \& S. Šebela, 1998: Denuded cavesan inherited element in the karst morphology; the case from Kras.- Acta carsologica, 27, 1, 165-174.

Mihevc, A., 1999: The caves and the karst surface-case study from Kras, Slovenia.- Etudes de géographie physique, suppl. 28, 141-144.

Peila, D. \& S. Pelizza, 2009: Ground probing and treatments in rock TBM tunnel to overcome limiting conditions.- Journal of Mining Science, 45, 6, 602-619.

Piccini, L., 2005: Morfologia ed evoluzione dei sistemi carsici delle Alpi Apuane.- Mem. Ist. Ital. Speleol., II, 18, 33-53.

Placer, L., 1981: Geologic Structure of SW Slovenia.- Geologija, 24, 1, 27-60.

Sancin, S., 1988: Recenti indagini sulle Sorgenti di Bagnoli.- Rassegna Federazione Speleologica Triestina, 35-38.

Sancin, S., 2008: Izviri pod Socerbsko planoto. - In: Gasparo, D. (Ed.) Glinscica in njena slikovita kraijna. Lindt Editor, pp. 27-34, Trieste.

Shang, Y., Xue, J., Wang, S., Yang, Z. \& J. Yang, 2004: A case history of Tunnel Boring Machine jamming in an inter-layer shear zone at the Yellow River Diversion Project in China.- Engineering Geology, 71, 199-211.

Slabe, T., 1997: Karst features discovered during motorway construction in Slovenia.- Environmental Geology, 32, 3, 186-190.

Šušteršič, F., 1994: Classic dolines of classical site. - Acta carsologica, 23, 123-154. 
Tirelli, T., Ravalico, M., Cucchi, F., Zini, L., Pugliese, N., Fanzutti, G.P., Fontana, A., Tunis, G., Fanucci, F., Covelli, S. \& R. Marocco, 2008: Carta di Sintesi Geologica GEO-CGT. 1:10000. Foglio 110-Trieste, Sezione 110150.- DiSGAM_Università di Trieste \& R.A. Friuli Venezia Giulia, Trieste.

Vincenti, V., Gargini, A. \& N. Goldscheider, 2009: Using tracer tests and hydrological observations to evaluate effects of tunnel drainage on groundwater and surface waters in the Northern Apennines (Italy). Hydrogeology Journal, 17, 135-150.
Visintin, L., 2007: Carsogenesi del settore meridionale del Carso Classico.- MSc. Thesis, University of Trieste, pp. 220.

Xeidakis, G.S., Torok, A., Skias, S. \& B. Kleb, 2004: Engineering geological problems associated with karst terrains: their investigation, monitoring, and mitigation and design of engineering structures on karst terrains.- Bulletin of the Geological Society of Greece, 36, 1932-1941. 